\title{
The Urgency of Utilizing Open Data Platform by the Foreigner Supervision Team to Promote Good Governance During the Covid-19 Pandemic
}

\author{
Rita Kusuma Astuti ${ }^{1, *}$ Koesmoyo Ponco Aji ${ }^{2}$ Wilonotomo ${ }^{3}$
}

\author{
${ }^{1}$ Undergraduate Program in Immigration Administration at the Polytechnic of Immigration, Indonesia, \\ ${ }^{2}$ Undergraduate Program in Migration Studies at the Immigration Polytechnic, Indonesia, \\ ${ }^{3}$ Undergraduate Program in Immigration Technology Management at the Immigration Polytechnic, Indonesia, \\ *Corresponding author. Email: ritakusumaastuti@gmail.com
}

\begin{abstract}
Ministry of Law and Human Rights governenace in Indonesia has entered the digital era. This is in line with government direction and hopes in the conception of Making Indonesia 4.0 in 2018. In terms of services, immigration control, and implementation of supporting facilitative elements, simultaneous immigration has entered the level of e-governance. One of them is in terms of coordination and open data exchange related to the existence and activities of foreigners by the Foreigner Supervision Team which consists of various related government agencies. The Foreigner Supervision Team covers three aspects, namely the coordination aspect and the supervision aspect as well as the repression aspect. The Foreigner Supervision Team is required to have an open media for exchanging information and data. This digital platform must include foreign data in accordance with the licensing documents issued by each agency. The grouping of data from agencies that are members of the Foreigner Supervision Team will later be managed and processed for decision making in any Foreigner Supervision activities carried out. In addition, this digital platform must be able to function as an online learning medium for each agency member of the foreign supervision team to understand the main duties and functions of each member. This is in line with the Ministry of Law and Human Rights program in realizing the Ministry of Law and Human Rights Corporate University. The purpose of this study is to reveal the important side of the implementation of coordination carried out by the Foreigner Supervision Team. Through empirical normative methods, this research attempts to provide critical thinking and new perspectives in the context of implementing coordination and open data exchange based on digital platforms.
\end{abstract}

Keywords: open data platform, foreigner supervision team, good governance in Indonesia.

\section{INTRODUCTION}

The industrial revolution 4.0 encourages the movement of people to migrate more easily than before. Several factors encourage people to immigrate, namely economic and non-economic factors which vary widely from person to person. In essence, every human being who migrates has the goal of getting a better life and increasing their level of welfare, especially from an economic perspective.

Each country has its own policies in regulating human traffic between countries and the supervision of its activities and existence. In the case of Indonesia, this is regulated based on the Immigration In this case, the Directorate General of Immigration
Law Number 6 of 2011 concerning Immigration, especially in Chapter VI that regulates Immigration Control. What is meant by Immigration is the matter of traffic of people entering or leaving the territory of the Republic of Indonesia and supervision of foreigners in the territory of the Republic of Indonesia [1]. The entry and exit of people, especially foreigners and during their existence in Indonesia, must bring benefits to national development and must be following national values and goals based on Pancasila and the 1945 Indonesian Constitution [2]. 
as one of the main units under the Ministry of Law and Human Rights of the Republic of Indonesia, has the main task of carrying out some of the main tasks of Ministry of Law and Human Rights in the field of Immigration in accordance with the provisions of laws and regulations. [3] The implementation of the immigration function is part of the affairs of state government in providing immigration services, law enforcement, state security, and facilitating the development of public welfare [4]. The implementationof these functions is carried out simultaneously, or simultaneously, not only by focusing on one function, in its implementation it uses the principle of "selective policy". In this principle, the regulation of entry and exit for everyone from and to the territory of Indonesia uses a measure, namely [5]:

(1) Can / do not provide benefits, welfare for the nation;

(2) Harm / not to security and order; and

(3) Hostile / not with the Indonesian people.

In fact, the political policy of immigration law is reflected in the duties of supervising foreigners regarding the whereabouts of foreigners, their existence and activities, since they enter, been to, and leave the territory of the Republic of Indonesia. For the implementation of Supervision of Foreigners, government regulations have been issued to regulate such matters [6].

In the Immigration Law, it is stated that in the context of immigration control of the activities of foreigners in Indonesia, the Minister of Law and Human Rights establishes a Foreigner Supervision Team whose members consist of relevant government agencies, both at the central and regional levels. [7]. Thus, it is clear that the implementation of the main duties of immigration does not only relate to the traffic problem of people entering and leaving the Indonesian territory but also the supervision for the presence and activities of foreigners while in the territory of Indonesia. This means that to carry out foreign monitoring activities, coordination with other relevant agencies is required. This is because the licensing of documents owned by foreigners is issued by different agencies according to their authority, as shown in the following table:

\begin{tabular}{|c|c|c|}
\hline Agency & Activity & Documents Required \\
\hline $\begin{array}{l}\text { Office of } \\
\text { Manpower and } \\
\text { Transmigration }\end{array}$ & $\begin{array}{l}\text { Work in the } \\
\text { working area of } \\
\text { the Class I } \\
\text { Immigration } \\
\text { Office in } \\
\text { Tangerang }\end{array}$ & 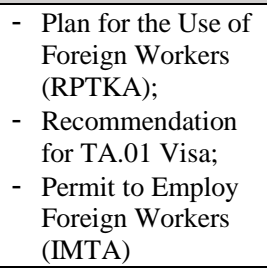 \\
\hline Police & $\begin{array}{l}\text { Work in the } \\
\text { working area of } \\
\text { the Class I } \\
\text { Immigration } \\
\text { Office in } \\
\text { Tangerang }\end{array}$ & $\begin{array}{ll}\text { - } & \text { Self-Report } \\
& \text { Certificate (SKLD) } \\
\text { - } & \text { Reporting } \\
& \text { Certificate (STM) }\end{array}$ \\
\hline $\begin{array}{l}\text { Civil and } \\
\text { Population } \\
\text { Registry Service }\end{array}$ & $\begin{array}{l}\text { Work in the } \\
\text { working area of } \\
\text { the Class I } \\
\text { Immigration } \\
\text { Office in } \\
\text { Tangerang }\end{array}$ & $\begin{array}{ll}\text { - } & \text { Temporary } \\
& \text { Resident } \\
\text { Registration } \\
\text { Certificate } \\
\text { (SKPPS) } \\
\text { - } & \text { Residence } \\
& \text { Certificate (SKTT) } \\
\end{array}$ \\
\hline $\begin{array}{lr}\text { Ministry } & \text { of } \\
\text { Religious } & \text { Affairs } \\
\text { office }\end{array}$ & $\begin{array}{l}\text { Conducting mixed } \\
\text { marriages with } \\
\text { Indonesian } \\
\text { citizens }\end{array}$ & $\begin{array}{l}\text { - Quote of Marriage } \\
\text { Certificate }\end{array}$ \\
\hline $\begin{array}{l}\text { Education } \\
\text { Authorities }\end{array}$ & $\begin{array}{l}\text { - Work as a } \\
\text { teaching staff; } \\
\text { - Studying at } \\
\text { educational } \\
\text { institutions }\end{array}$ & $\begin{array}{ll}\text { - } & \text { Limited residence } \\
& \text { visa, } \\
\text { - } & \text { Limited Stay Permit } \\
& \text { Card, } \\
\text { - } & \text { Permanent } \\
& \text { Residence Permit } \\
& \text { Card, } \\
\text { - } & \text { Foreigner } \\
& \text { Registration (POA) }\end{array}$ \\
\hline
\end{tabular}

Table 1. Related agencies and products of foreigner licensing documents in the framework of the Foreigner Supervision Team (Law Number 2 of 2002 concerning the National Police of the Republic of Indonesia, Law Number 6 of 2011 concerning Immigration, Law Number 13 of 2003 concerning Manpower, Law Number 23 of 2006 concerning Population Administration) [8]

With regard to the permit to stay and carry out activities in Indonesia, foreigners need an immigration permit that is in accordance with its intention [9]. To ensure that there are no matters that are contrary to the regulations regarding the presence and activities of foreigners in Indonesia, it is better if integrated supervision is carried out to create a synergy between powers and government institutions, because in this way different perceptions can be woven into one channel for one purpose, that is, there are no violations by foreigners and for the sake of law enforcement [10]. This is also regulated in the Regulation of the Minister of Law and Human Rights of the Republic of Indonesia Number 50 of 2016 concerning the Foreigner Supervision Team. Chapter IV describes the duties 
and functions of the Foreigner Supervision Team (Tim Pora).

In Article 15 [11], it is stated that the Tim Pora Members have to provide advice and considerations to related government agencies and/or institutions, regarding matters related to Foreigner Supervision. For this reason, in carrying out the tasks referred to earlier, the Tim Pora has the following functions:

(1) coordination and exchange of data and information;

(2) collecting information and data on the existence of foreigners in stages from the village or subdistrict to the provincial level;

(3) analyzing and evaluating data/information relating to the implementation of the Control of Foreigners and making maps of the Supervision of Foreigners

(4) solving problems with the existence and activities of foreigners;

(5) implementing and regulating relations and cooperation in the framework of Foreigner Supervision;

(6) preparating special or incidental joint operation plans including independent operation plans for each agency member of the Tim Pora; and

(7) implementating other functions stipulated by the Tim Pora Leader relating to the Supervision of Foreigners.

For this reason, it is necessary to improve coordination between related agencies, speed, and accuracy of information exchange so that the information presented can be used for accurate decision making. The coordination of the supervision of foreigners must be carried out in an integrated manner between the executors of the relevant agencies so that there is no overlap, confusion, and egosectoral in the implementation of supervisory duties without neglecting the principles of coordination, integration, and synchronization of regulations and the implementation of supervision of foreigners. Supervision of the existence and activities of foreigners is not entirely in the hands of the Immigration Agency. All components of the nation need to be involved so that foreigners do not freely commit violations and comply with applicable legal norms. Through coordination between agencies, a more effective and efficient exchange and division of tasks between agencies can be obtained.

Based on the aforementioned matters, coordination between agencies is necessary considering the number of foreigners residing in Indonesian territory, as shown in the Immigration Data table for the period 2015-2019, as follows:

\begin{tabular}{|c|c|c|}
\hline $\begin{array}{c}\text { Data of the } \\
\text { Crossing }\end{array}$ & Departure & Arrival \\
\hline Year 2015 & 9.321 .654 & 9.349 .479 \\
\hline Year 2016 & 9.734 .957 & 9.767 .293 \\
\hline Year 2017 & 11.076 .104 & 11.110 .837 \\
\hline Year 2018 & 12.181 .553 & 12.129 .319 \\
\hline Year 2019 & 9.457 .524 & 9.452 .546 \\
\hline
\end{tabular}

Tablel 2. Data of the Crossing of Foreigners for 2015-2019 Directorate General of Immigration (2020). [12]

\begin{tabular}{|c|c|c|c|c|c|}
\hline $\begin{array}{c}\text { Type of } \\
\text { Residence } \\
\text { Permit }\end{array}$ & $\begin{array}{l}\text { Year } \\
2015\end{array}$ & $\begin{array}{l}\text { Year } \\
2016\end{array}$ & $\begin{array}{l}\text { Year } \\
2017\end{array}$ & $\begin{array}{l}\text { Year } \\
2018\end{array}$ & $\begin{array}{l}\text { Year } \\
2019\end{array}$ \\
\hline $\begin{array}{l}\text { Visit Stay } \\
\text { Permit } \\
\text { (ITK) }\end{array}$ & 265.380 & 274.641 & 284.144 & 270.425 & 168.166 \\
\hline $\begin{array}{l}\text { Limited } \\
\text { Stay Permit } \\
\text { (ITAS) for } \\
\text { non- } \\
\text { workers }\end{array}$ & 71.438 & 69.268 & 59.802 & 50.719 & 12.338 \\
\hline $\begin{array}{l}\text { Limited } \\
\text { Stay Permit } \\
\text { (ITAS) for } \\
\text { workers }\end{array}$ & 118.102 & 122.243 & 108.047 & 104.027 & 56.012 \\
\hline $\begin{array}{l}\text { Permanent } \\
\text { Residence } \\
\text { Permit } \\
\text { (ITAP) for } \\
\text { non- } \\
\text { workers } \\
\end{array}$ & 3.256 & 3.269 & 3.476 & 2.419 & 1.409 \\
\hline $\begin{array}{l}\text { Permanent } \\
\text { Stay Permit } \\
\text { (ITAP) for } \\
\text { workers }\end{array}$ & 907 & 1.056 & 879 & 670 & 223 \\
\hline Grand Total & 459.083 & 470.477 & 456.348 & 428.260 & 238.148 \\
\hline
\end{tabular}

Table 3. Directorate General of Immigration (2020). Data on the Issuance of Immigration Permits for Foreigners (ITK, ITAS and ITAP) for 2015-2019 [13]

Furthermore, referring to the implementation provisions related to procedures for immigration control of foreigners, it is stated that the Administrative Supervision of Foreigners as referred to in these provisions is carried out by [14]:

(1) collecting, processing, and presentating data and information regarding Immigration services for foreigners, foreigner traffic entering or leaving the Indonesian territory, foreigners who have received a detention decision, foreigners who are in the process of determining Immigration status and/or Immigration action, foreigners who get a permit outside the Immigration Detention Center after the detention period has passed and foreigners in the criminal justice process.

(2) preparating a list of names of foreigners who are subject to prevention and deterrence; and

(3) taking photos and fingerprint. 
Meanwhile, data and information as referred to in the previous paragraph are determined as confidential data. In this provision, it is stated that the data and information as contained in the Immigration Management and Information System (SIMKIM) must be accessible by related government agencies and/or institutions following their respective duties and functions. Related to data access, it can be done based on a memorandum of understanding or an agreement between the Ministry of Law and Human Rights or the Directorate General of Immigration with related government agencies and / or institutions [15].

Referring to this regulation, the exchange of data and information should be carried out in solving the problem of the presence of foreigners. The data and information must be accessible by the relevant agencies and based on a memorandum of understanding between the Ministry of Law and Human Rights or the Directorate General of Immigration and related government agencies and/or institutions. Tim Pora does not yet have a digital information media platform that allows Tim Pora members to interact online and exchange information related to updated data. The urgency of the need for a digital media platform for information exchange is urged by the number of criminal acts committed in the border area of the Republic of Indonesia (NKRI), where immigration is in charge as the gatekeeper of the country, shown in the following picture:

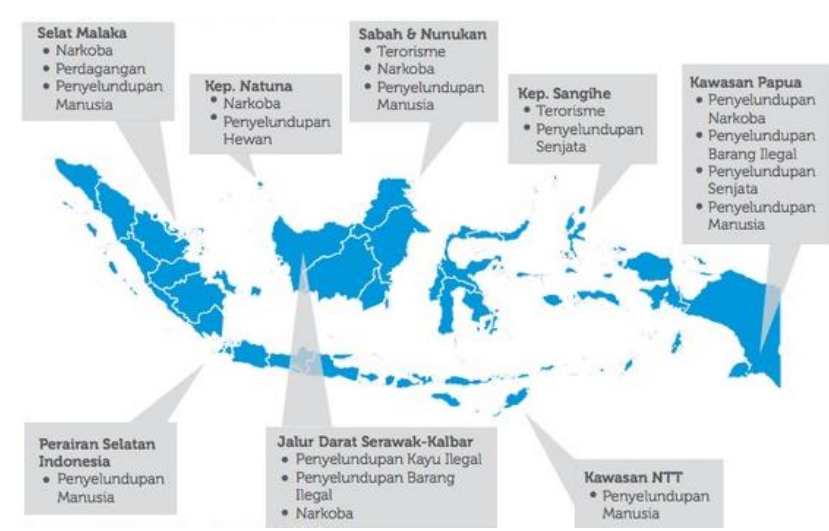

Figure 1 map of vulnerability to crime and criminal acts in the border area of Indonesia

Presidential Regulation number 18 of 2020 concerning the 2020-2024 National Medium-Term Development Plan - Attachment I [16]

The geographical condition of Indonesia, which is an archipelagic country, makes it possible for migration between countries to occur through small, unsupervised routes. This is vulnerable to violations by foreigners when entering the Indonesian borders.
The current systematic implementation of the Tim Pora in accordance with the Standard Operating Procedures issued by the Directorate General of Immigration are as follows:

(1) The legal basis for the formation of the Tim Pora, namely the issuance of the Decree of the Head of the Immigration Office (Tim Pora at Regency / District level) regarding the formation of Team Pora members;

(2) Coordination is carried out through correspondence to carry out coordination meeting activities;

(3) Coordination meeting. At this meeting all Tim Pora members are invited to discuss work plan, coordination of activities to be carried out, exchange of data and information, and distribution of the results of the meeting. It can be concluded that the exchange of information on foreigner data is only through this coordination meeting;

(4) Tim Pora Leader establishes a joint operation plan and carries out supervisory activities through the joint Tim Pora operations. The findings in the field, related to the alleged occurrence of violations committed by captured foreigners, are submitted to the respective authorities;

(5) Evaluation Meeting. After the completion of the joint operations of the Tim Pora, a report on the joint operations of the Tim Pora is carried out.

The current problem is that the coordination that has been carried out in the supervision of foreigners so far is only through the media of letters, coordination meetings, and joint operations of Tim Pora members. The legal basis for the activities of the Tim Pora is only based on the Decree of the Tim Pora members, where there is no memorandum of understanding that regulates the exchange of data and information. The exchange of information is carried out manually, which is not against the principles in implementing e-government. Egovernment is the use of the internet network in disseminating information and government services to the public [17]

In accordance with the Presidential Instruction on national policies and strategies for e-government development, it was stated that the government must immediately carry out the transformation process towards e-government [18]. Through this transformation process, the government can optimize the use of advances in information technology to eliminate the boundaries of bureaucratic organizations and form a network of management systems and work processes that allow government agencies to work in an integrated manner to simplify access to all information and public services that 
must be provided by the government. In this way, all state institutions, the public, the business world, and other interested parties can make optimal use of government information and services at any time. For this reason, strong leadership is needed in each institution or government unit so that the transformation process towards e-government can be carried out efficiently. The delivery of information in two directions can occur between governmentsociety, public-private, and between government agencies, which in turn will increase the efficiency of government performance [19].

This is related to the current pandemic. Starting at the end of 2019, the outbreak of Corona Virus Disease 2019 in China's Wuhan province, led the World Health Organization (WHO) announced that the Covid-19 outbreak was a global pandemic since March 11, 2020. Due to its status as a global pandemic, Indonesia was also affected by the outbreak. the. President Joko Widodo emphasized that policies for productive activities at home need to be implemented to reduce the spread of Covid-19. Meanwhile, these activities are mainly related to work, study, as well as worship. President Joko Widodo, in a press conference at the Bogor Palace on Monday, March 16, 2020, conveys that the policy of studying from home, working from home, and worshiping at home needs to be intensified to reduce the spread of Covid-19. [20].

As a follow-up to the President's instructions, the Ministry of Administrative and Bureaucratic Reform (PANRB) provides a national policy on adjusting the work system of the State Civil Apparatus during the outbreak of Covid-19. This policy is contained in the Circular of the Minister for Empowerment of State Apparatus and Bureaucratic Reform, where this provision serves as a guideline for government agencies in carrying out official duties by working at home/residence (Work from Home) as an effort to prevent and minimize the spread of Covid- 19. The purpose of this Circular Letter is [21]:

(1) To prevent and minimize the spread, and reduce the risk of Covid-19 in government agencies in particular and the wider community at large.

(2) To ensure that the implementation of duties and functions of each government agency can run effectively to achieve the performance of each organizational unit in government agencies.

(3) To ensure that the implementation of public services in government agencies continue to run effectively.

In accordance with directions from the Ministry of Administrative Reform and Bureaucratic Reform, performance activities are carried out online. Indirectly, this will also affect the surveillance activities of foreigners. However, non of Tim Pora activities is carried out online, particularly those related to open information management. Almost every agency is currently developing online application media to make it easier for them to carry out their main tasks and functions. This is of course according to the implementation of good governance in implementing e-government and is part of the 4.0 industrial revolution [22].

\section{RESEARCH METHODS}

The research method used is normativeempirical, which is is a combination of the normative legal approach with the addition of various empirical elements. The normative-empirical research method examines the implementation of normative legal provisions (laws and regulations) in action in any particular legal event that occurs in a society [23].

This paper discusses normative provisions regarding the Foreigner Supervision Team and digital platforms used by the government. With empirical thinking about the problems found related to the open data platform put forward by the researchers, it is hoped that it can provide solutions in information exchange and coordination online, especially during the Covid-19 pandemic.

\section{FINDINGS AND DISCUSSION}

In supervising foreigners, the final result that is achieved is a legal action for the violations committed. The following is data on immigration law enforcement for 2015-2018:

\begin{tabular}{|c|c|c|}
\hline $\begin{array}{c}\text { Type of } \\
\text { Action }\end{array}$ & $\begin{array}{c}\text { Immigration } \\
\text { Administrative } \\
\text { Action }\end{array}$ & $\begin{array}{c}\text { Immigration } \\
\text { Investigation } \\
\text { (Pro Justitia) }\end{array}$ \\
\hline Year 2015 & 18.392 & 255 \\
\hline Year 2016 & 7.926 & 341 \\
\hline Year 2017 & 9.191 & 273 \\
\hline Year 2018 & 11.769 & 119 \\
\hline
\end{tabular}

Table 4. Immigration Law Enforcement Data

Directorate General of Immigration (2020). [24]

The number presented above is small when compared to the data on the number of foreigners who have residence permits in Indonesia. To improve the performance of the Tim Pora, the coordination and exchange of information must be maximized. The implementation of coordination, especially between government agencies, is not easy and it needs adjustment and harmonization of each of the tasks and functions into a common perception. 
Often ego sectoral, overlapping transfer of authority causes failure in coordination.

According to Malone and Crowston, coordination is an emphasis lies in interdependence. Without dependency, there is nothing to coordinate. The main aim of Malone and Crowston was to synthesize the work being done on the coordination of various fields. So it can be concluded that coordination is a management of dependency between activities [25].

Sugandha, in his book Coordinating the Unifying Tool of Administrative Movement, formulates that: Coordination is the unifying movement of all potentials and organizational units or organizations with different functions so that they lead to the same goal to facilitate efficient achievement [26]. Regarding the position of coordination, which is considered important in an organization or management, Hasibuan stated that [27]:

(1) To prevent chaos, squabbling and twins or vacancies.

(2) So that people and their work are aligned and directed to achieve company goals.

(3) So that all elements of management (6M) and the work of each individual employee must help achieve organizational goals.

(4) So that all tasks and activities and jobs are integrated to the desired target.

Communication is the key to effective coordination. Direct coordination depends on obtaining, disseminating, and processing information. The greater the uncertainty of the coordinated tasks, the more information is required. For this reason, coordination is primarily an information processing task [28]. For that, a system of fast and accurate information exchange is needed so that coordination can run effectively.

When viewed from the Medium-Term Development Plan (RPJMN) IV 2020-2024, there are 7 agendas, namely [29]:

(1) Strengthening Economic Resilience for Quality Growth;

(2) Developing Areas to Reduce Inequality;

(3) Increasing Quality and Competitive Human Resources;

(4) Building Culture and National Character;

(5) Strengthening Infrastructure to Support Economic Development and Basic Services;

(6) Building the Environment, Enhancing Disaster Resilience and Climate Change;

(7) Strengthening the Stability of Politics, Defense and Security and Transformation of Public Services.
To be able to accelerate the National Medium Term Development Plan IV 2020-2024, and to accelerate the achievement of national development targets, 6 (six) mainstream goals have been established as a form of innovative approach that will become a catalyst for equitable and adaptive national development. They play a vital role in national development while still paying attention to environmental sustainability and community participation. In addition to accelerating the achievement of targets from a development focus, they also aim to provide equitable access to development by increasing government efficiency and adapting to external environmental factors. This needs to be done by Indonesia to achieve global goals. The 6 (six) mainstream goals are [30]:

(1) Gender Equality

The national development strategy must include a gender perspective to achieve a more equitable development for all Indonesian citizens, both men, and women.

(2) Good Governance

Accountable, effective, and efficient governance in supporting improved performance in all dimensions of development.

(3) Sustainable Development

Sustainable development must be able to maintain the sustainability of the economic and social life of the community, maintain the quality of the environment, and promote inclusive development and the implementation of governance having the ability maintain the improvement of the quality of life from one generation to the next.

(4) Disaster Vulnerability and Climate Change Mainstreaming of Disaster Vulnerability and Climate Change focuses on efforts to mitigate and reduce disaster vulnerability, increase resilience to climate change risks, and increase climate change mitigation through the implementation of low carbon development.

(5) Social and Cultural Capital

Mainstreaming socio-cultural capital is intended to internalize cultural values and utilize cultural wealth as a driving force and basic capital of development.

(6) Digital Transformation

The rapid development of technology, especially digital technology, has affected various aspects of life.

Mainstreaming that will be focused in the monitoring activities of Tim Pora is through Good Governance and Digital Transformation. Good governance, according to UNDP, is participation, law enforcement, transparency, responsiveness, consensus-oriented, fairness, effectiveness and 
efficiency, accountability, and strategic vision. It is stated that one of the triggers for the formation of good governance in Indonesia is the increasing demands of society for the quality of democracy, threat of human rights, and ineffective governance so that people with full awareness are willing to ask the government to be more responsible and transparent [31]

\subsection{Good Governance}

Members of the Tim Pora consist of a group of State Civil Servants from various related agencies. The State Civil Apparatus, both individually and as an organization under it, has a strategic role to supervise and make decisions on foreigners who are suspected of committing immigration violations, or violations related to the authority of other agencies. According to the RPJMN agenda above, the government has issued a Presidential Regulation on an Electoral Based Government System (SPBE) [32].

SPBE is a system that organizes electronic-based governance, by utilizing information and communication technology to provide services to SPBE users in an integrated manner both intraagency and inter-agency. The final expected result is to create clean, effective, transparent, and accountable governance and quality and reliable public services. This is what supports civil servants who are increasingly required to be professional, have integrity, neutral, creative, innovative, and competitive, and are supported by a bureaucracy that is simpler, more adaptive, and opens up spaces for public participation in government [33].

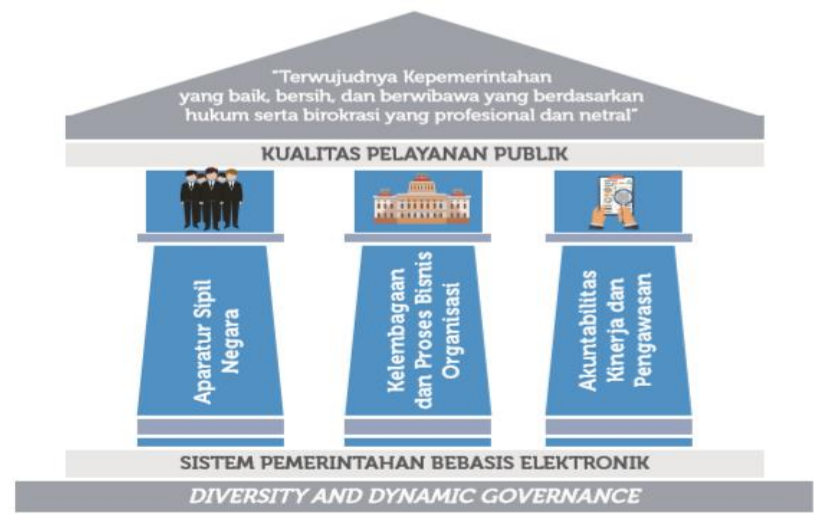

Figure 2 Bureaucratic Institutional Reform Presidential Regulation number 18 of 2020 concerning the 2020-2024 National Medium-Term Development Plan - Attachment I

\subsection{Digital Transformation}

To be able to carry out the process of exchanging information between agencies within the Tim Pora members, it can be seen in the digital transformation trend as follows [34]:

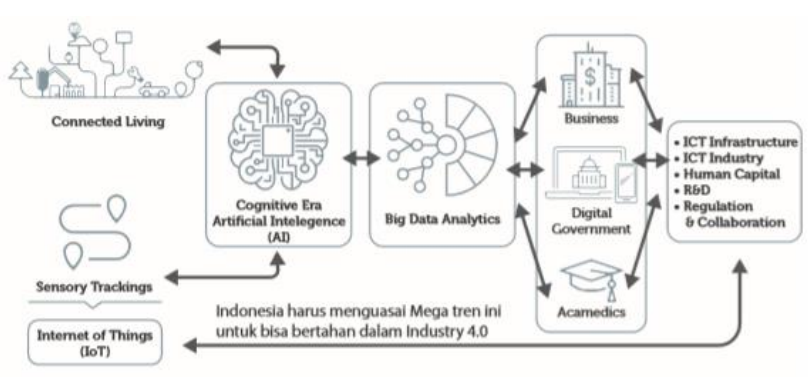

Figure 3 Future Digital Transformation Trends Presidential Regulation number 18 Year 2020 concerning the 2020-2024 National Medium-Term Development Plan [35]

Based on this picture, it can be concluded that every life will be related to one another through various sophisticated sensory tracking tools or via the internet so that it can improve cognitive intelligence and artificial intelligence. This can be in the form of information and communication technology in the fields of infrastructure, industry, human resources, research and development, regulation, and collaboration. Indonesia must master this mega trend to survive in the Industry 4.0 era. The following are the goals and policy directions used for Digital Transformation:

\begin{tabular}{|c|c|c|}
\hline & $\begin{array}{l}\text { Indonesia } \\
\text { Digital }\end{array}$ & $\begin{array}{c}\text { Digital } \\
\text { Government }\end{array}$ \\
\hline $\begin{array}{l}\text { Digital } \\
\text { Transformation } \\
\text { Goals }\end{array}$ & $\begin{array}{l}\text { - Indonesia that } \\
\text { is developed, } \\
\text { independent, } \\
\text { just, and } \\
\text { prosperous } \\
\text { with the help } \\
\text { of digital } \\
\text { technology; } \\
5 \text { focus of } \\
\text { development, } \\
\text { namely human, } \\
\text { economy, } \\
\text { region, } \\
\text { infrastructure, } \\
\text { and political } \\
\text { security } \\
\text { defense law. } \\
\text { Among others, } \\
\text { in health and } \\
\text { education } \\
\text { services, } \\
\text { financial }\end{array}$ & 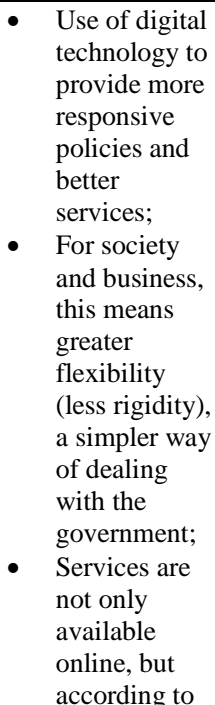 \\
\hline
\end{tabular}




\begin{tabular}{|c|c|c|}
\hline & $\begin{array}{l}\text { services } \\
\text { (fintech), } \\
\text { government } \\
\text { services } \\
\text { (digital } \\
\text { government), } \\
\text { mobility } \\
\text { services, low- } \\
\text { carbon } \\
\text { development, } \\
\text { digital } \\
\text { generation } \\
\text { infrastructure, } \\
\text { government } \\
\text { cooperation } \\
\text { and business } \\
\text { entities, smart } \\
\text { cities, smart } \\
\text { agriculture; } \\
\text { A suitable } \\
\text { environment } \\
\text { for developing } \\
\text { business and } \\
\text { R\&D. } \\
\end{array}$ & $\begin{array}{l}\text { the needs of } \\
\text { society and } \\
\text { business } \\
\text { (based on Big } \\
\text { Data). Service } \\
\text { is more } \\
\text { personal, } \\
\text { focused. }\end{array}$ \\
\hline $\begin{array}{l}\text { Policy } \\
\text { Direction }\end{array}$ & \multicolumn{2}{|c|}{$\begin{array}{l}\text { Develop conditions that encourage } \\
\text { the development of digital service } \\
\text { provision such as capacity building } \\
\text { for human resources, technology, } \\
\text { R\&D, infrastructure, and establishing } \\
\text { supporting regulations and } \\
\text { institutions; } \\
\text { - Identify the fulfillment of digital } \\
\text { services and integrate digital } \\
\text { transformation systems nationally; } \\
\text { - Developing skills in Big Data } \\
\text { management; } \\
\text { - Strengthening cooperation between } \\
\text { government, private sector, } \\
\text { academics and the community. }\end{array}$} \\
\hline
\end{tabular}

Table 5. Digital Transformation

Presidential Regulation number 18 Year 2020 concerning the 2020-2024 National Medium-Term Development Plan [36]

Based on the explanation above, the Tim Pora should have a digital platform in the form of open data and can be accessed by all team members. The digital platform must also allow each member to coordinate digitally because the information needed in supervising foreigners must be available in realtime. In addition, the coordination that was often carried out among the Tim Pora members is with regard to the validity of the permit documents issued by other related agencies. Proof of the validity of the original document can also be used as legal evidence if needed. The Tim Pora digital platform must have Big Data that can be used for the purpose of monitoring foreigners. In the future, analysis in Big Data will be used as a basis for decision making and for taking action on violations committed by foreigners.

\subsection{Improvement of Human Resources through Corporate University}

As stated in the previous chapter, one of the development agendas of the RPJMN IV for 20202024 is to increase Quality and Competitive Human Resources. In relation to the performance of the Tim Pora, every State Civil Apparatus who is part of the Tim Pora must understand its main duties, functions, and authorities. This is to avoid overlapping or duplication of supervision and sectoral egos between agencies in the field later.

Corporate University is an organizational learning approach to employee development intended to support organizational performance. This is what Kemenkumham intends to implement to support the performance of the State Civil Apparatus. At the time of its declaration, the Secretary-General of the Ministry of Law and Human Rights hoped that the ministry's move to become a Corporate University was a continuous progression of learning in every ministry implementation. The development of a Corporate University is a concrete action in the framework of developing superior human resources. He stated that Corporate University was built to train employees to carry out their duties appropriately and efficiently. Besides, the aim of building a Corporate University is to improve the competence of State Civil Apparatus. This was conveyed by the SecretaryGeneral at the Coordination Meeting for the Acceleration of Performance Progress of the Secretariat General Unit in November 2019 [37].

In line with this, the Minister of Law and Human Rights, said that the construction of the Ministry of Law and Human Rights of the Corporate University was an act concrete aspects that must be realized in the framework of developing superior Human Resources. Corporate University must be up to date, based on information technology, and able to answer strategic issues [38].

\begin{tabular}{|l|l|l|l|}
\hline Factor & University & $\begin{array}{c}\text { Education } \\
\text { and } \\
\text { Training } \\
\text { Center }\end{array}$ & $\begin{array}{l}\text { Corporate } \\
\text { University }\end{array}$ \\
\hline Focus & Education & $\begin{array}{l}\text { Operational } \\
\text { needs }\end{array}$ & $\begin{array}{l}\text { Business needs } \\
\text { the main } \\
\text { activity of the } \\
\text { organization) }\end{array}$ \\
\hline Service & $\begin{array}{l}\text { Reactive/ } \\
\text { proactive }\end{array}$ & Reactive & proactive \\
\hline Process & $\begin{array}{l}\text { Focusing on } \\
\text { lecturers, } \\
\text { teaching } \\
\text { trainers }\end{array}$ & $\begin{array}{l}\text { Fragmented } \\
\text { per training } \\
\text { program }\end{array}$ & $\begin{array}{l}\text { Integrated, } \\
\text { followed by } \\
\text { concrete action } \\
\text { in the form of } \\
\text { on the job } \\
\text { training }\end{array}$ \\
\hline
\end{tabular}




\begin{tabular}{|l|l|l|l|}
\hline Method & $\begin{array}{l}\text { The learning } \\
\text { program is } \\
\text { structured to } \\
\text { be } \\
\text { completed } \\
\text { within a } \\
\text { certain } \\
\text { period }\end{array}$ & $\begin{array}{l}\text { Limited to } \\
\text { ongoing } \\
\text { training }\end{array}$ & $\begin{array}{l}\text { Blended } \\
\text { learning, } \\
\text { between } \\
\text { practice and } \\
\text { learning in the } \\
\text { classroom. } \\
\text { Utilization of } \\
\text { technology as } \\
\text { a medium for } \\
\text { effective } \\
\text { learning. }\end{array}$ \\
\hline Theory & $\begin{array}{l}\text { General } \\
\text { abilities }\end{array}$ & $\begin{array}{l}\text { Individual } \\
\text { technical } \\
\text { abilities }\end{array}$ & $\begin{array}{l}\text { Core } \\
\text { organizational } \\
\text { capabilities. }\end{array}$ \\
\hline Role & $\begin{array}{l}\text { Educational } \\
\text { Institution }\end{array}$ & $\begin{array}{l}\text { Education, } \\
\text { training and } \\
\text { development } \\
\text { part of Human } \\
\text { Capital } \\
\text { Management } \\
\text { and achieving } \\
\text { the } \\
\text { organization's } \\
\text { business } \\
\text { targets. }\end{array}$ \\
\hline
\end{tabular}

Table 6. Differences between Universities, Education and Training Centers and Corporate Universities

Nike Mutiara Fauziah dan Andri Wahyu Prasetyo (2019). ASN Corporate University: A Concept of Civil Service Education and Training in the Disruptive Era. Jurnal Kebijakan dan Manajemen PNS. Vol 13 No 2 Nov (2019) [39]

In line with the hopes of the high leadership of the Ministry of Law and Human Rights above, the use of the digital open data platform on the Tim Pora can be used for the learning process for officers or State Civil Servants, through mentors and distance learning between agencies. So members of the Tim Pora at the Immigration Office can also find out the authority of each agency. In the corporate university pocketbook, the Ministry of Law and Human Rights explains the urgency of corporate university learning, which are [40]:

(1) Applicative, adaptive, and high impact learning needs;

(2) Knowledge is more easily transmitted to others and accessed because it is well documented;

(3) Opportunities for broader competency development;

(4) The development of information technology in the learning process;

(5) The demands of the Bureaucratic world-class, the Industry Revolution 4.0;

(6) Human resource development needs that are in line with the Strategic Plan.

This is in line with the learning model carried out through the Corporate University, namely through the e-learning method. Learn independently and deepen the capabilities and performance of each agency, in addition to exchanging information regarding the main tasks and functions of each agency so that authority and sectoral egos do not overlap.

\section{CONCLUSION}

Supervision is carried out on foreigners related to their activities and presence in the territory of the Unitary State of the Republic of Indonesia, not only by Immigration. However, it is also carried out by other relevant agencies that are members of the Foreigner Supervision Team. Immigration as the leading sector in the activities of Tim Pora does not yet have a digital platform used for coordination and exchange of data and information.

The urgency of using an open data platform is needed, considering that Tim Pora members must always coordinate with other related agencies. The information needed in monitoring foreigners must be real-time and integrated. As a consequence, they can have the ability to know the problems and violations committed by the foreigner and can immediately take required actions against the foreigner.

The open data digital platform on the Tim Pora can also be used for the implementation of the organizational learning process online to develop the resources of the State Civil Apparatus through the Corporate University. In this Digital Platform, State Civil Servants who are members of the Tim Pora can learn their main tasks and functions so that sectoral egos and overlapping can be avoided.

Regarding the urgency of coordination between related agencies in the Tim Pora, an Open Digital Data Platform is needed, as regulated in Presidential Regulation Number 95 of 2018 concerning Electronic-Based Government Systems (SPBE) to realize Good Governance. The platform will allow the process of exchanging information electronically which in turn will allow acceleration of the decisionmaking process for violations committed by foreigners. Thus, the actions against the violations committed will increase, and Immigration as the guardian of the State borderd will be able to carry out its function optimally.

\section{REFERENCES}

[1] Indonesia, Article 1 Number 1. Law Number 6 Year 2011 concerning Immigration. State Gazette of the Republic of Indonesia of 2011 Number 52. 2011.

[2] Paragraph 9, General Chapter. Elucidation of Law Number 6 Year 2011 concerning Immigration. Supplement to the State Gazette of the Republic of Indonesia Number 5216. 
[3] Article 548. Regulation of the Minister of Law and Human Rights of the Republic of Indonesia Number 29 of 2015 concerning Organization and Work Procedure of the Ministry of Law and Human Rights of the Republic of Indonesia.

[4] Op.Cit. Article 1 Number 5, Law Number 6 Year 2011 concerning Immigration.

[5] Op.Cit.Paragraph 9, General Chapter. Elucidation of Law Number 6 Year 2011 concerning Immigration.

[6] Website of the Directorate General of Immigration. Product of law. Accesed from: https://www.imigrasi.go.id/produk_hukum/ind ex/undang-undang.

[7] Op.Cit. Article 69 Paragraph (1) of Law Number 6 Year 2011 concerning Immigration. State Gazette of the Republic of Indonesia of 2011 Number 52. 2011.

[8] Law Number 2 of 2002 concerning the National Police of the Republic of Indonesia, Law Number 6 of 2011 concerning Immigration, Law Number 13 of 2003 concerning Manpower, Law Number 23 of 2006 concerning Population Administration.

[9] Op.Cit. Article 48 Paragraph (1) jo. Article 122. Law Number 6 Year 2011 concerning Immigration.

[10] Website of the Directorate General of Immigration. OrangAsing Supervision. Accesed from: http://www.imigrasi.go.id/index.php?option=c om_content\&task=view\&id=338\&Itemid=34.

[11] Regulation of the Minister of Law and Human Rights of the Republic of Indonesia Number 50 Year 2016 concerning the Foreigner Supervision Team.

[12] Directorate General of Immigration (2020). Data of the Crossing of Foreigners for 20152019.

[13] Directorate General of Immigration (2020) Data on the Issuance of Immigration Permits for Foreigners (ITK, ITAS and ITAP) for 2015-2019.

[14] Regulation of the Minister of Law and Human Rights of the Republic of Indonesia Number 4 of 2017 concerning Immigration Control Procedures, Chapter IV Procedures for Immigration Control Against Foreigners Article 34.

[15] Ibid.

[16] Presidential Regulation number 18 of 2020 concerning the 2020-2024 National MediumTerm Development Plan - Attachment I.

[17] Maya Septiani (2020). E-Government Sebagai
Strategi dalam Meminimalisasi Penyebaran Covid-19 dan Efektivitas Pelayanan Publik. Ombudsman Republik Indonesia. Accessed from:

https://ombudsman.go.id/artikel/r/artikel--egovernment-sebagai-strategi-dalammeminimalisasi-penyebaran-covid-19-danefektivitas-pelayanan-publik.

[18] Presidential Instruction number 3 of 2003 concerning National Policy and Strategy for E-Government Development, in Appendix I point 5

[19] Ibid.

[20] Biro Pers, Media, dan Informasi Sekretariat Presiden (2020). Konferensi Pers Presiden Di Istana Bogor Senin, 16 Maret 2020 17:30 Wib. Accessed from: https://www.presidenri.go.id/siaranpers/arahan-presiden-terkait-kebijakanpemerintah-pusat-dan-daerah-tangani-covid$19 /$.

[21] Circular of the Minister for Empowerment of State Apparatus and Bureaucratic Reform Number 19 Year 2020 concerning Adjustments to the Work System of State Civil Apparatus in Efforts to Prevent Covid19 in Government Agencies.

[22] Website of the Minister for Empowerment of State Apparatus and Bureaucratic Reform (2020). Prevention of the Spread of the Covid19 Virus by Working at Home for ASN, 16 March 2020. Accesed from: https://menpan.go.id/site/beritaterkini/pencegahan-penyebaran-virus-covid19-dengan-kerja-di-rumah-bagi-asn.

[23] Vera Wheni S. Soemarwi (2017). Tinjauan Normatif-Empiris Asas Partisipatif dalam Perencanaan Pembangunan Kota: Normalisasi Kali Ciliwung di Bukit Duri, Jurnal Muara Ilmu Sosial, Humaniora, dan Seni. Universitas Tarumanagara, Vol. 1, No, 1. April 2017 : hlm 232-239. ISSN 2579-6348.

[24] Directorate General of Immigration (2020). Data of Immigration Law Enforcement.

[25] Kevin Crowston, Joseph Rubleske, and James Howison (1994). Coordination Theory. Journal. citeseerx.ist.psu.edu/viewdoc/download?doi= 10.1.1.59.7748\&rep=rep1\&type=pdf

[26] Daan Sugandha (1998). Koordinasi. Jakarta: Intermedia.

[27] Malayu S. P. Hasibuan (1996). Manajemen Dasar, Pengertian dan Masalah. Jakarta: Gunung Agung.

[28] T. Hani Handoko (2003). Manajemen, Edisi 2. Yogyakarta: BPFE, 
[29] Ibid. Presidential Regulation number 18 Year 2020 concerning the 2020-2024 National Medium-Term Development Plan.

[30] Ibid.

[31] Al Mukholis Siagian (2019). Tata Kelola Pemerintahan ang Baik (Good Governance) dalam Pembangunan Berkelanjutan (SDGs). Accessed from: https://www.kompasiana.com/almukhollissiag ian/5d19ca2a097f362c6624ccf2/tata-kelolapemerintahan-yang-baik-good-governancedalam-pembangunan-berkelanjutansdgs?page $=$ all

[32] Presidential Regulation number 95 Year 2018 concerning Electoral-Based Government Systems.

[33] Op.Cit. Presidential Regulation number 18 Year 2020 concerning the 2020-2024 National Medium-Term Development Plan.

[34] Ibid.

[35] Ibid.

[36] Ibid. Attachment 1.

[37] Biro Humas Kementerian Hukum dan HAM RI (2019). Pembangunan SDM Unggul Melalui Corporate University. Accessed from: https://www.kemenkumham.go.id/berita/pemb angunan-sdm-unggul-melalui-corporateuniversity

[38] Biro Humas, Hukum dan Kerjasama (2019) Kemenkumham Corporate University, Solusi Bangun SDM Kemenkumham yang Unggul. Accessed from: https://www.kemenkumham.go.id/berita/keme nkumham-corporate-university-solusi-bangunsdm-kemenkumham-yang-unggul

[39] Nike Mutiara Fauziah dan Andri Wahyu Prasetyo (2019). ASN Corporate University: A Concept of Civil Service Education and Training in the Disruptive Era. Jurnal Kebijakan dan Manajemen. PNS, Vol 13 No 2 Nov (2019)

[40] Biro Humas, Hukum dan Kerjasama (2019). Buku Saku Corporate University Kementerian Hukum dan Hak Asasi Manusia RI. 